\title{
Status of the Quaternary: Your opinion sought
}

The International Commission on Stratigraphy (ICS), a body of the International Union of Geological Sciences (IUGS), is in the process of standardizing the geological time scale, a task to be completed before the next International Geological Congress in 2008.

\section{Quaternary task force}

In 1985, with the placement of the base of the Pleistocene GSSP, "The subject of defining the boundary between the Pliocene and Pleistocene was isolated from other more or less related problems, such as the pending definition of the Calabrian, and the status of the Quaternary within the chronostratigraphic scale" [Aguirre, E., Pasini, G., The Pliocene-Pleistocene boundary, Episodes 8 (1985) 116-120]. For various reasons, the "pending definition... and status of the Quaternary" were never formally resolved nor submitted to ICS/IUGS for consideration or ratification.

Following the International Geological Congress in 2004 in Florence, INQUA and ICS set up a task force to consider the issue. The task force was charged with making a recommendation, within $1 \mathrm{yr}$, to ICS on the definition and possible rank of the Quaternary on the geological time scale. It issued its report before a meeting of ICS in Leuven, Belgium, in September 2005. Its recommendation to ICS was as follows:

(1) That the Quaternary should be recognized as a formal chronostratigraphic/geochronologic unit.

(2) That the lower boundary of the Quaternary should coincide with the base of the Gelasian Stage (2.6 Ma) and thus be defined by the Gelasian GSSP.

(3) That the Quaternary will have the rank of either:

(a) System/Period at the top of the Neogene System/ Period, with its lower boundary marking the top of a shortened Neogene, or

(b) Sub-Erathem/Sub-Era correlative with the upper part of the Neogene System/Period.

\section{ICS decision}

Following extended discussion at Leuven, the ICS voting membership unanimously voted, by a show of hands, that the
Quaternary be recognized as a formal chronostratigraphic/ geochronologic unit with a lower boundary coinciding with the base of the Gelasian Stage and defined by the Gelasian GSSP. The voting membership considered several options for the rank of the Quaternary and voted on the options by a show of hands. Only one option received a majority: that the Quaternary have the rank of Sub-Erathem/Sub-Era. Subsequently, a written ballot was held on this single issue, i.e., whether or not the Quaternary should have the rank of Sub-Erathem/Sub-Era. The voting membership consisted of the executive officers of ICS and the chairs of the ICS subcommissions. The final vote on the Sub-Erathem/Sub-Era option was:

\begin{tabular}{ll}
\hline Yes & 12 votes \\
No & 5 votes \\
Abstain & 1 vote \\
\hline
\end{tabular}

The result is that the lower boundary of the Quaternary would be defined at the base of the Gelasian Stage, at 2.6 Ma. Through an early polling of the Quaternary community, INQUA found that the vast majority of Quaternary scientists favor a 2.6-Ma boundary over the current $1.8 \mathrm{Ma}$ one. A further result is that the Quaternary, although firmly formalized as a chronostratigraphic/geochronologic unit, would not be a System/Period above the Neogene. The Neogene would extend from the base of the Miocene to the present.

\section{What now?}

INQUA informed ICS, prior to the Leuven meeting, that it would consult the Quaternary community prior to deciding whether to support the new ICS position on the Quaternary. The INQUA Executive Committee is thus seeking your opinion. Please let us know whether the ICS proposal is acceptable to you or not. Below, I summarize this option and what the Executive Committee considers to be its pros and cons.

\section{Definition of the quaternary}

The Quaternary is a Sub-Erathem/Sub-Era correlative with the upper part of the Neogene System/Period and with a lower 
boundary coincident with the base of the Gelasian Stage (2.6 Ma) (Fig. 1).

\section{Pros}

- Quaternary is a formal chronostratigraphic/geochronologic unit, with a standardized definition and would be displayed on the international geological time scale.

- Base of the Quaternary is pinned at 2.6 Ma.

- ICS has accepted this option.

\section{Cons}

- The Quaternary is not a Period/System.

- The base of the Quaternary and that of the Pleistocene Epoch are not the same (the base of the Pleistocene remains at 1.8 Ma; the base of the Quaternary becomes 2.6 Ma).

Two other options have been discussed:

Option 2. The Quaternary is a Period/System above the Neogene, comprising the Pleistocene and Holocene epochs with a base at the base of the Gelasian Stage $(2.6 \mathrm{Ma})$.

Option 3. Same as Option 2 except that the lower boundary of the Quaternary coincides with the base of the Pleistocene (1.8 Ma). Many Quaternary researchers consider this option the status quo.

ICS has made it clear that it will not accept option 2, and it likely will not accept option 3. Thus, unless IUGS were to side with INQUA against its own commission and could convince ICS to accept the Quaternary as a Period, the term will not have a standardized definition or formal ratified status on the geological time scale. INQUA might lobby IUGS to reject ICS's revised time scale, with the hope that it would instruct ICS to accept Option 2, but it seems unlikely that it would interfere in this manner with one of its commissions.

What would be the consequences if the "Quaternary" was not formally included in the geological time scale? The term would continue to be used, albeit informally, much as the "Precambrian" is used today. However, the stature of the

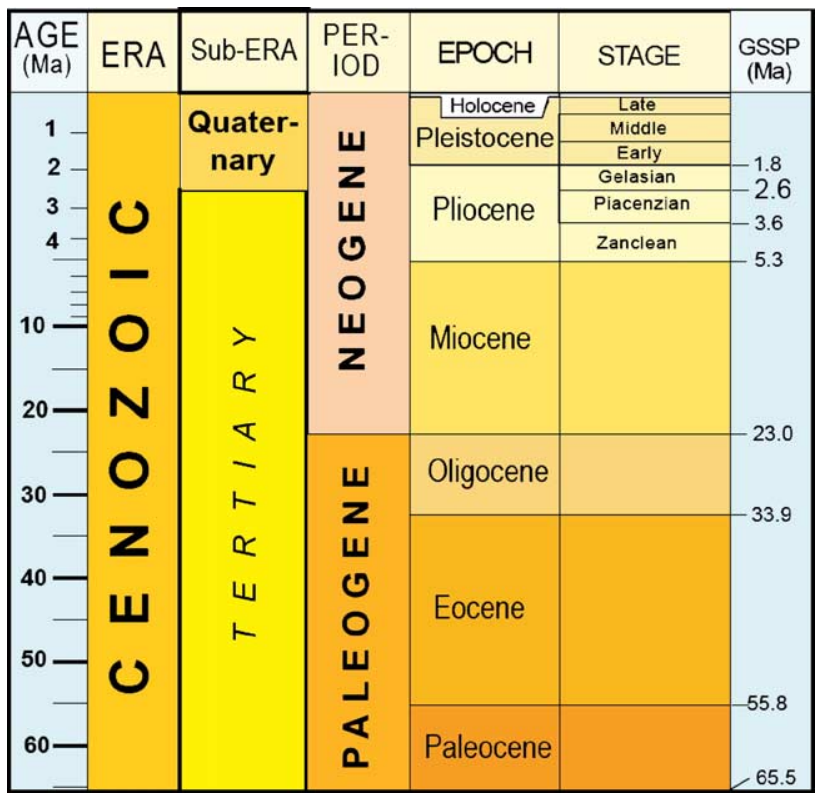

Figure 1. Subdivisions of the Cenozoic Era proposed by ICS, with the Quaternary defined as a Sub-Erathem/Sub-Era with a base at 2.6 Ma.

Quaternary, and more importantly our field of study, likely would be diminished, with uncertain future consequences. It might be difficult to have the Quaternary added to the geological time scale at a later date.

\section{Your opinion please}

The INQUA Executive Committee asks that you give careful thought to this important issue and let John Clague (jclague@sfu.ca) know whether you consider the ICS proposal acceptable or unacceptable. Please take the time to respond, because the opinions of the Quaternary community will guide the Executive Committee in its response to ICS. A simple oneword response is adequate, but the Executive Committee welcomes comments on the issue. The deadline for comments is February 15, 2006.

John Clague

President, INQUA 